Article

\title{
DMFC Performance of Polymer Electrolyte Membranes Prepared from a Graft-Copolymer Consisting of a Polysulfone Main Chain and Styrene Sulfonic Acid Side Chains
}

\author{
Nobutaka Endo ${ }^{1}$, Yoshiaki Ogawa ${ }^{1}$, Kohei Ukai ${ }^{1}$, Yuriko Kakihana ${ }^{2}$ and Mitsuru Higa ${ }^{1, *}$ \\ 1 Graduate School of Science and Technology for Innovation, Yamaguchi University, 2-16-1 Tokiwadai, \\ Ube City, Yamaguchi 755-8611, Japan; n-endo@yamaguchi-u.ac.jp (N.E.); xpsjj881@ybb.ne.jp (Y.O.); \\ 1.24.kou@gmail.com (K.U.) \\ 2 Center for Membrane and Film Technology, Department of Chemical Science and Engineering, \\ Kobe University, 1-1 Rokkodaicho, Nada-ku, Kobe 657-8501, Japan; kakihana@people.kobe-u.ac.jp \\ * Correspondence: mhiga@yamaguchi-u.ac.jp; Tel.: +81-836-85-9203; Fax: +81-836-85-9601
}

Academic Editor: Vladimir Gurau

Received: 4 July 2016; Accepted: 10 August 2016; Published: 19 August 2016

\begin{abstract}
Polymer electrolyte membranes (PEMs) for direct methanol fuel cell (DMFC) applications were prepared from a graft-copolymer (PSF- $g$-PSSA) consisting of a polysulfone (PSF) main chain and poly(styrene sulfonic acid) (PSSA) side chains with various average distances between side chains (Lav) and side chain lengths (Lsc). The polymers were synthesized by grafting ethyl $p$-styrenesulfonate (EtSS) on macro-initiators of chloromethylated polysulfone with different contents of chloromethyl (CM) groups, and by changing EtSS content in the copolymers by using atom transfer radical polymerization (ATRP). The DMFC performance tests using membrane electrode assemblis (MEAs) with the three types of the PEMs revealed that: a PSF-g-PSSA PEM (SF-6) prepared from a graft copolymer with short average distances between side chains (Lav) and medium Lsc had higher DMFC performance than PEMs with long Lav and long Lsc or with short Lav and short Lsc. SF-6 had about two times higher $P D_{\max }\left(68.4 \mathrm{~mW} / \mathrm{cm}^{2}\right)$ than Nafion ${ }^{\circledR} 112$ at $30 \mathrm{wt} \%$ of methanol concentration. Furthermore, it had $58.2 \mathrm{~mW} / \mathrm{cm}^{2}$ of $P D_{\max }$ at $50 \mathrm{wt} \%$ of methanol concentration because of it has the highest proton selectivity during DMFC operation of all the PSF-g-PSSA PEMs and Nafion ${ }^{\circledR} 112$.
\end{abstract}

Keywords: polysulfone; graft-copolymer; atom-transfer radical polymerization; polymer electrolyte membrane; direct methanol fuel cell

\section{Introduction}

Direct methanol fuel cells (DMFCs) using polymer electrolyte membranes (PEMs) represent one of the most attractive power sources because of their stable operation at relatively low temperatures, the high energy density obtained by using highly concentrated methanol solutions as fuel, and their simplicity [1,2]. Nafion ${ }^{\circledR}$ (DuPont)-based PEMs have been used most frequently for DMFCs [3-9]. However, their high methanol permeability is one the critical drawbacks in their application as PEMs for DMFC systems. In the past decades, there have been many reports focusing on alternative aromatic PEM materials [10], such as sulfonated poly(aryl ether)s (SPAEs) [11-15], sulfonated poly(ether ether ketone)s (SPEEKs) [16,17], sulfonated polyimides (SPIs) [18-24], and so on.

One of the effective strategies to get both high proton conductivity and low methanol permeability is to develop PEMs prepared from graft copolymers consisting of two chemically different polymer segments: a main chain made from a polymer with low methanol permeability and side chains made from a polymer having proton conductive properties. Zhang and Russell [25] 
recently reported partially-fluorinated graft copolymers of poly([vinylidene difluoride-cochlorotrifluoroethylene]- $g$-styrene) [P(VDF-co-CTFE)- $g$-PS] prepared by graft-atom transfer radical polymerization (g-ATRP) of styrene from commercial $\mathrm{P}(\mathrm{VDF}-\mathrm{Co}-\mathrm{CTFE})$. Shi et al. reported the preparation of proton conducting partially sulfonated P(VDF-co-CTFE)- $g$-SPS graft copolymers by $g$-ATRP of styrene from P(VDF-co-CTFE) macro-initiators followed by post-sulfonation [26]. One of the synthesis methods to prepare a graft copolymer using aromatic polymers is to perform chlorometylation of the polymers and then to use the chloromethylated polymers as a macro-initiator of atom transfer radical polymerization (ATRP) [27,28]. In a previous study [29], cation-exchange membranes (CEMs) were prepared from a graft copolymer consisting of a polysulfone (PSF) main chain and poly(styrene sulfonic acid) (PSSA) side chains (PSF-g-PSSA) synthesized by grafting styrene sulfonic acid side chains on a chloromethylated polysulfone (CM-PSF) main chain as a macro-initiator of ATRP. A proposed chemical structure of the graft-copolymer is shown in Figure 1. The CEMs had both higher counter-ion selectivity and lower membrane resistance than commercially-available CEMs.

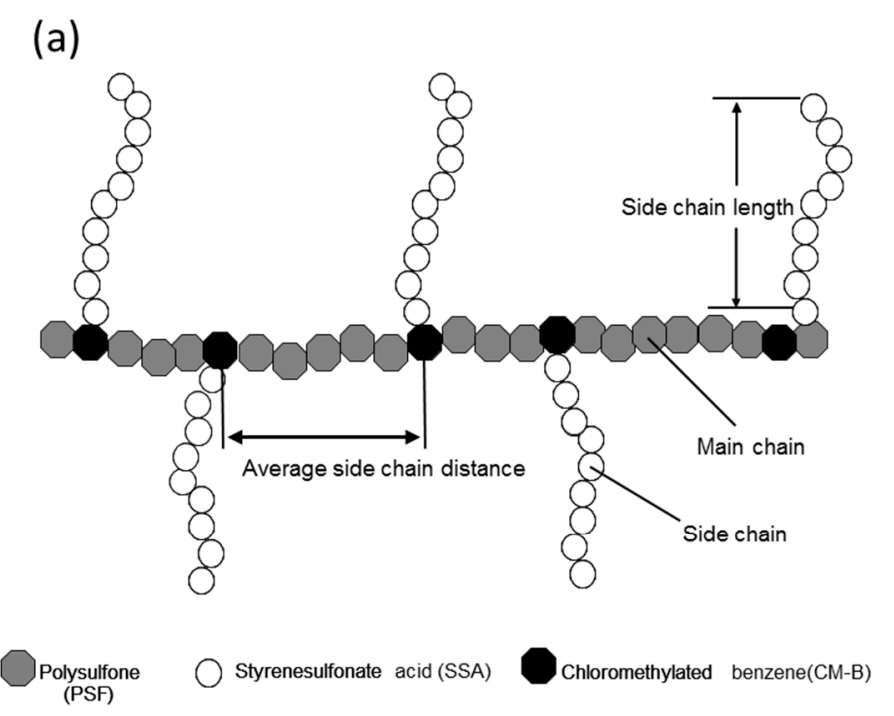

(b)

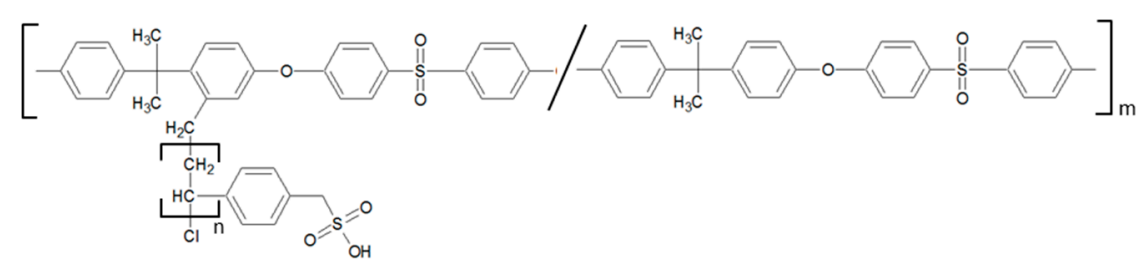

Figure 1. (a) Proposed structure and (b) chemical structure of a graft-copolymer consisting of a polysulfone main chain and poly(styrene sulfonic acid) side chains (PSF-g-PSSA).

In this study, high-performance PEMs for DMFC systems were prepared from the PSF- $g$-PSSA graft copolymers. The correlation between the polymer structures: (a) the average distance between graft side chains and (b) side chain length, and the properties of the PEMs for DMFC systems such as water uptake, proton conductivity, methanol permeability, cell voltage, and power density at a DMFC test, and in situ conductivity and methanol permeability during DMFC operation, were investigated.

\section{Experimental Section}

\subsection{Preparation of Polymer Electrolyte Membranes for DMFCS}

The CM-PSF used as a macro-initiator of ATRP, and the graft copolymer synthesized by grafting EtSS monomer on the CM-PSF using the ATRP method, were prepared according to the same 
method as in a previous study [29]. PSF $\left(\mathrm{M}_{\mathrm{w}}=75,000 \mathrm{~g} / \mathrm{mol}\right.$; Sigma-Aldrich Chemical Co., Ltd., Tokyo, Japan) was reacted with chloromethylmethylether (CMME: Tokyo Chemical Industry Co., Ltd., Tokyo, Japan) in dichloroethane containing zinc oxide (ZnO: Wako Pure Chemicals Ind., Ltd., Osaka, Japan), changing the CMME content in the reaction mixture. The CM-PSFs obtained were reacted with the various amounts of $p$-ethyl styrenesulfonate (EtSS: Tosoh Co., Ltd., Tokyo, Japan) in 1-methyl-2-pyrrolidinone (NMP: Sigma-Aldrich Chemical Co., Ltd.) containing copper (I) chloride (CuCl: Sigma-Aldrich Chemical Co., Ltd.) and 4,4'-dimethyl-2,2'-dipyridyl (bpy: Sigma-Aldrich Chemical Co., Ltd.) at $90{ }^{\circ} \mathrm{C}$ for $48 \mathrm{~h}$. The resultant mixtures were precipitated into a petroleum ether/ethanol $/ \mathrm{HCl}$ solution. The obtained graft copolymers were dried in a vacuum at $80{ }^{\circ} \mathrm{C}$ to constant weight. Nuclear magnetic resonance (NMR) spectra were performed on the macro-initiators and the graft-copolymers using a spectrometer for ${ }^{1} \mathrm{H}$ (JEOL JNM-EX270FT NMR system, Tokyo, Japan). $\mathrm{CDCl}_{3}$ and DMSO- $d_{6}$ was used as the solvent and tetramethylsilane as an internal standard. The data were analyzed using commercially available software (JEOL DATYM Ltd., ALICE2, Tokyo, Japan) to estimate the chloromethyl group content in the macro-initiators and the EtSS content in the graft copolymers. Precursor PEMs were prepared by casting a tetrahydrofuran solution of the PSF-g-EtSS graft copolymers on glass plate, followed by evaporating the solvent and further by drying under high vacuum for over $12 \mathrm{~h}$ at room temperature. Sulfonated PSF graft copolymer (PSF-g-SSA) PEMs were prepared by immersing the precursor PEMs in hot water $\left(95^{\circ} \mathrm{C}\right)$ for $24 \mathrm{~h}$ to remove the ethyl groups of EtSS by hydrolysis reaction.

\subsection{Measurement of Water Uptake}

The water uptake of the PEMs in deionized water was measured as follows: the PEMs were weighed in the dry state and then immersed in deionized water at $25^{\circ} \mathrm{C}$ for one week. The PEMs were removed from the water, tapped with filter paper to remove excess surface water, and then weighed in the wet state. The water uptake in deionized water, $W U$, was calculated from the PEMs' weights in the wet state, $W_{W}$, and in the dry state, $W_{D}$, as $W U=\left(W_{W}-W_{D}\right) / W_{D}$.

\subsection{Measurement of Ion-Exchange Capacity (IEC)}

IEC is expressed as milliequivalents per gram of PEM (meq/g-dry-PEM) and was determined as follows: a sample PEM was immersed in $0.10 \mathrm{M} \mathrm{KCl}$ solution for $3 \mathrm{~h}$ before measuring the IEC. The PEM was rinsed with deionized water to remove non-exchanged $\mathrm{KCl}$ electrolyte adsorbed on the PEM and was then immersed in $50 \mathrm{~cm}^{3}$ of $0.20 \mathrm{M} \mathrm{NaNO}_{3}$ for $12 \mathrm{~h}$, under stirring, to achieve the complete exchange of $\mathrm{K}^{+}$ions in the PEM with $\mathrm{Na}^{+}$ions in the solution. The concentration of $\mathrm{K}^{+}$ions in the solution, $C_{K+}$, was determined using an ion chromatograph (Dionex ICS-1500; Thermo Fisher Scientific, Inc., Waltham, MA, USA). The PEM was dried under vacuum for $24 \mathrm{~h}$ and was weighed in the dry state, $W_{D}$. The IEC of the precursor membrane was calculated using the following equation:

$$
I E C=\frac{C_{K+}}{W_{D}} \times \frac{50}{1000}
$$

\subsection{Measurement of Proton Conductivity}

Each PEM sample was immersed in $0.10 \mathrm{M} \mathrm{HCl}$ for $1 \mathrm{~h}$. The PEM was removed from the solution, tapped with filter paper to remove excess $\mathrm{HCl}$ solution on the surface, and then sandwiched with two stainless steel electrodes. The proton conductivity of the PEMs at $60^{\circ} \mathrm{C}$ was determined by an AC impedance technique using an electrochemical impedance analyzer (3532-80, Hioki E. E. Corp., Nagano, Japan), where the AC frequency was scanned from $4 \mathrm{kHz}$ to $100 \mathrm{~Hz}$ at a voltage amplitude of $0.05 \mathrm{~V}$. The proton conductivity was calculated from the following equation:

$$
\sigma=\frac{d}{R S}
$$


where $\sigma$ is the proton conductivity and $d, R$, and $S$ are the thickness, measured impedance, and the surface area of the PEM, respectively.

\subsection{Measurement of Methanol Permeability}

Permeation experiments were performed using an acrylic plastic cell comprising two parts separated by a sample PEM [30]. The PEMs were equilibrated in a $12 \mathrm{M}$ methanol aqueous solution for at least $24 \mathrm{~h}$ prior to the experiments. One chamber (chamber I) of the cell was filled with $12 \mathrm{M}$ methanol solution, and the other (chamber II) was filled with deionized water. The volumes of chambers I and II were 400 and $100 \mathrm{~cm}^{3}$, respectively. The effective membrane area of the apparatus was $2.54 \mathrm{~cm}^{2}$. Methanol diffused from chamber I to chamber II, based on the concentration gradient between the two chambers, which were well stirred during the measurements. The concentration of methanol in chamber II $\left(\mathrm{C}^{I I}\right)$ was measured using flow injection (FI) method with flowing ultrapure water at $40{ }^{\circ} \mathrm{C}$. The FI apparatus consists of a high performance liquid chromatography (HPLC) system: a pump (PU-980 Intelligent HPLC Pump, Jasco Corp., Tokyo, Japan), a refractive index monitor (RI-2031 Plus Intelligent RI Detector, Jasco Corp., Tokyo, Japan) and an auto sampler (AS-2055 Plus Intelligent Sampler, Jasco Corp., Tokyo, Japan).

The methanol permeability, $P_{\mathrm{L} / \mathrm{L}}$, through the PEM was then determined from the slope of the time-concentration curve of methanol in chamber II as expressed in the following equation:

$$
P_{L / L}=\frac{V^{I I} d}{\left(C_{0}^{I}-C_{0}^{I I}\right) s} \times \frac{\Delta C^{I I}}{\Delta t}
$$

where $C^{I}{ }_{0}$ and $C^{I I}{ }_{0}$ are the initial methanol concentrations in chambers I and II, respectively. $V^{I I}$ is the volume of chamber II, and $S$ and $d$ are the area and thickness of the sample PEM, respectively. $\Delta C^{I I} / \Delta t$ is the initial slope of the time-concentration curve for chamber II.

\subsection{Fabrication of Membrane Electrode Assemblis (MEAs) and Evaluation of Single-Cell Performance}

Pt, Ru/C (\#45372, Johnson Matthey Plc., Tochigi, Japan) and Pt/C (\#45372, Johnson Matthey Plc., Tochigi, Japan) were used as the anode and cathode electrode, respectively. Both anode and cathode electrodes were impregnated with a small amount of Nafion solution as a binder. The effective area was $5 \mathrm{~cm}^{2}$. The MEA was set in a single cell test fixture. DMFC measurements were performed using a DMFC test station (EIWA Corp., Osaka, Japan) with a FC impedance meter (KFM2030, KIKUSUI Electronics Corp., Kanagawa, Japan) at $40-80{ }^{\circ} \mathrm{C}$. An aqueous methanol solution (5-50 wt \%) was fed to the anode at a flow rate of $1.0 \mathrm{~mL} / \mathrm{min}$, oxygen was fed to the cathode at $150 \mathrm{~N} \cdot \mathrm{cm}^{3} / \mathrm{min}$ under air atmosphere.

Alternating current (AC) impedance analysis was performed under steady-state conditions. The frequency range was from $0.1 \mathrm{~Hz}$ to $10 \mathrm{kHz}$ and the load current was set at $100 \mathrm{~mA} / \mathrm{cm}^{2}$. The cell resistance and electrode reaction resistance were determined by the AC impedance cole-cole plots. The proton conductivity during DMFC operation in thickness direction of a PEM $\left(\sigma_{\mathrm{DMFC}}\right)$ was evaluated by assuming that the PEM resistance is approximately equal to the cell resistance.

The methanol crossover through a PEM during DMFC operation was measured as described elsewhere [31]. The measurement apparatus is shown in Figure 2. The cathode effluent was conducted to a cold trap $\left(<-40{ }^{\circ} \mathrm{C}\right)$ to condense the water and methanol vapor and then the dried gas was conducted to a gas sampler for gas chromatography to measure the $\mathrm{CO}_{2}$ content. The condensed liquid was weighed and then subjected to the flow injection method (described above) to determine the methanol content.

The methanol permeation flux ( $\left.q_{\text {DMFC }}\right)$ was calculated from the following equations:

$$
q_{D M F C}=\frac{M_{\mathrm{CO} 2}+M_{\mathrm{MeOH}}}{S_{M E A} t_{m e a}}
$$


where $M_{\mathrm{CO} 2}$ and $M_{\mathrm{MeOH}}$ are the $\mathrm{CO}_{2}$ amount and methanol amount, respectively, flowed into the cathode outlet stream for the measurement time, $t_{\text {mea }}$ and $S_{M E A}$ is the effective area of the MEA. The methanol permeability $\left(P_{\mathrm{DMFC}}\right)$ during DMFC operation was evaluated from the following equation, assuming that the PEM was in contact with the feed methanol solution and feed cathode gas:

$$
P_{D M F C}=\frac{q_{M} d}{C_{M}}
$$

where $C_{M}$ is a methanol concentration in feed and $d$ is the thickness of the PEM.

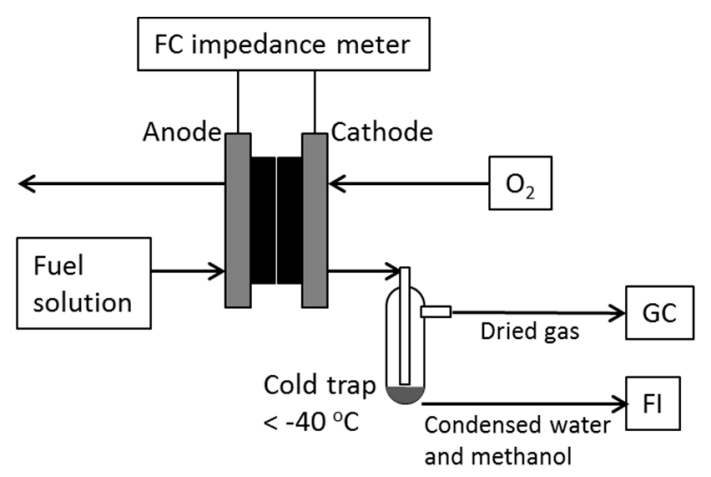

Figure 2. Schematic diagram of measurement apparatus for methanol crossover in DMFC operation.

\section{Results and Discussion}

\subsection{Characterization of the Synthesized Polymer and Membrane}

The synthesis conditions and polymerization data of the macro-initiator, CM-PSF, are listed in Table 1. The content of the chloromethyl $(\mathrm{CM})$ groups in the macro-initiator $\left(c^{\mathrm{P}} \mathrm{CM}\right)$ is defined as the number of CM groups per repeat unit [29] and calculated by comparison of the integration values of $-\mathrm{CH}_{2} \mathrm{Cl}$ protons at $4.6 \mathrm{ppm}$ with those of aromatic protons at the $-\mathrm{CH}_{3}$ in PSF at $1.7 \mathrm{ppm}$ of ${ }^{1} \mathrm{H} \mathrm{NMR}$ $\left(\mathrm{CDCl}_{3}\right)$ spectrum of CM-PSF and PSF, whose data are not shown here. The content of CM groups in the macro-initiator varied from $1.81 \mathrm{~mol} \%$ to $15.3 \mathrm{~mol} \%$, depending on the CMME contents in feed solution ( $c^{\mathrm{m}}$ CMME). Graft-copolymers (PSF- $g$-PSSA) were synthesized using the obtained CM-PSF as a macro-initiator for ATRP. The synthesis conditions of the graft copolymers are listed in Table 2. PEMs were prepared from the graft copolymers. The characteristics of the obtained PEMs are listed in Table 3. The IEC value of the PEMs varied from 0.43 to $1.52 \mathrm{meq} / \mathrm{g}$, and increased with increasing EtSS content in the reaction mixture, and also increased with CMME contents in feed solution because of the increase of the CM groups in the macro-initiator. The proposed structure of the graft copolymer shown in Figure 1 has main chain length, average distance between the graft side chains (Lav) and side chain length (Lsc). The average distance between the graft side chains should decrease with increase in the content of $\mathrm{CM}$ groups $\left(c^{\mathrm{P}} \mathrm{CM}\right)$ in the macro-initiator, CM-PSF. The value of $L s c$ will be proportional to the division of IEC by $c^{\mathrm{P}}{ }_{\mathrm{CM}}$. Hence, graft copolymers with $1.81 \mathrm{~mol} \%, 8.42 \mathrm{~mol} \%$ and $15.3 \mathrm{~mol} \%$ of $c^{\mathrm{P}} \mathrm{CM}$ will have long, medium, and short Lav, respectively. SF-3 and SF-5 had almost the same IEC of around $0.6 \mathrm{meq} / \mathrm{g}$, and SF-4 and SF-6 also had almost the same IEC of around $1.5 \mathrm{meq} / \mathrm{g}$. SF-3 and SF-5 were prepared from the graft polymer with $8.42 \mathrm{~mol} \%$ and $15.3 \mathrm{~mol} \%$ of $c^{\mathrm{P}}{ }_{\mathrm{CM}}$, respectively. These indicate that SF-3 has shorter Lsc and longer Lav than SF-5. The same relationship in the polymer structure will apply between SF-4 and SF-6. In comparison with PEMs with almost the same IECs, PEMs with medium Lsc (SF-4 and SF-6) had higher WU and proton conductivity than those with short Lsc (SF-3 and SF-5). This may be due to the fact that in the PEMs with shorter Lsc, it is difficult for the hydrophilic domains, which are formed by PSSA side chains, and take an important role in the proton conductivity of the PEMs, to be connected to each other. The weak connection between the hydrophilic domains may give SF-3 and SF-5 low WU and low proton conductivity. 
Table 1. Synthesis conditions and polymerization data of the macro-initiator (MI).

\begin{tabular}{|c|c|c|c|c|c|}
\hline MI & PSF (g) & $c^{\mathrm{m}}$ CMME $(\mathrm{mmol})$ & $c^{\mathrm{m}_{\mathrm{ZnO}}}(\mathrm{mmol})$ & $T_{\mathrm{r}}^{1}(\min )$ & $c^{\mathrm{p}_{\mathrm{cm}}}{ }^{2}(\mathrm{~mol} \%)$ \\
\hline CM-PSF-1 & 6.0 & 3.3 & 1.28 & 180 & 1.81 \\
\hline CM-PSF-2 & 6.0 & 13.2 & 1.28 & 180 & 8.42 \\
\hline CM-PSF-3 & 6.0 & 19.8 & 1.28 & 180 & 15.3 \\
\hline
\end{tabular}

${ }^{1}$ Reaction time at $50{ }^{\circ} \mathrm{C} ;{ }^{2}$ Chloromethyl group content of macroinitiator.

Table 2. Synthesis conditions of the graft copolymer, PSF-g-PSSA.

\begin{tabular}{ccccc}
\hline Graft copolymer & $\left.c^{\mathbf{p}} \mathbf{c m}^{\mathbf{1}} \mathbf{( \mathbf { m o l }} \mathbf{\%}\right)$ & EtSS $\mathbf{( m m o l})$ & $\mathbf{B p y}(\mathbf{m m o l})$ & $\mathbf{C u C l}(\mathbf{m m o l})$ \\
\hline PSF-g-PSSA-1 & 1.81 & 1.1 & 0.22 & 0.11 \\
PSF- - -PSSA-2 & 1.81 & 2.2 & 0.22 & 0.11 \\
PSF-g-PSSA-3 & 8.42 & 1.1 & 1.02 & 0.51 \\
PSF-g-PSSA-4 & 8.42 & 2.2 & 1.02 & 0.51 \\
PSF- $g$-PSSA-5 & 15.3 & 1.1 & 1.83 & 0.92 \\
PSF- $g$-PSSA-6 & 15.3 & 2.2 & 1.83 & 0.92 \\
\hline
\end{tabular}

${ }^{1}$ Chloromethyl group content of macroinitiator.

Table 3. Thickness $(d)$, ion exchange capacity $(I E C)$, water uptake $(W U)$, proton conductivity $(\sigma)$, methanol permeability $\left(P_{\mathrm{L} / \mathrm{L}}\right)$, and proton permselectivity $(\phi)$ of PSF-g-PSSA PEMs.

\begin{tabular}{ccccccc}
\hline PEM & $\boldsymbol{d}(\boldsymbol{\mu \mathrm { m } )}$ & $\boldsymbol{I E C}(\mathbf{m e q} / \mathrm{g})$ & $\boldsymbol{W U}(\mathbf{\%})$ & $\boldsymbol{\sigma}(\mathbf{m S} / \mathbf{c m})$ & $\boldsymbol{P}_{\mathbf{L} / \mathbf{L}}\left(\mathbf{1 0}^{-\mathbf{7}} \mathbf{c m}^{\mathbf{2}} / \mathbf{s}\right)$ & $\boldsymbol{\phi}\left(\mathbf{1 0} \mathbf{3} \cdot \mathbf{s} / \mathbf{c m}^{\mathbf{3}}\right)$ \\
\hline SF-1 & 60 & 0.43 & 36 & 0.024 & 0.038 & 6.5 \\
SF-2 & 60 & 0.83 & 144 & 27.1 & 5.6 & 48.6 \\
SF-3 & 30 & 0.61 & 78 & 3.5 & 7.3 & 4.8 \\
SF-4 & 167 & 1.55 & 283 & 33.6 & 21.7 & 15.5 \\
SF-5 & 50 & 0.64 & 111 & 3.7 & 9.5 & 3.9 \\
SF-6 & 70 & 1.52 & 386 & 103.4 & 46.7 & 22.2 \\
\hline
\end{tabular}

\subsection{Water Uptake, Proton Conductivity, and Methanol Permeability of the PEMs}

The water uptake of PEMs is an important property because both proton conductivity and methanol permeability depend on water uptake. Figure 3 shows the water uptake of PEMs as a function of IEC. The WU increased with increasing IEC and almost on a curve independent of the values of $c^{\mathrm{P}} \mathrm{CM}$ because the osmotic pressure in PEMs increases with increasing the number of proton-exchange groups in the PEMs.

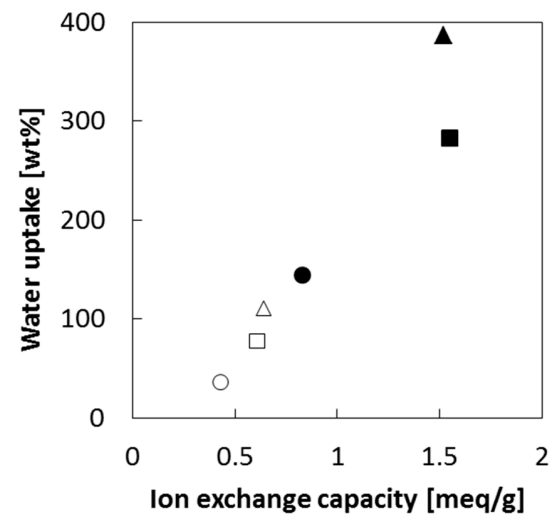

Figure 3. Water uptake of the PEMs as a function of ion exchange capacity. Chloromethyl group content in the polymers (mol \%): circles, 1.8; squares, 8.4; and triangles, 15.3. EtSS content in the reaction mixture (mmol): open symbols, 1.1 ; and solid symbols, 2.2 .

Figure 4 shows the proton conductivity of the PEMs at $60{ }^{\circ} \mathrm{C}$ as a function of water uptake. Proton conductivity increased with increasing water uptake. The increase in proton conductivity 
will be due to two factors: the increase in the number and/or the effective area of proton permeable channels and the increase of proton mobility in a PEM [32,33].

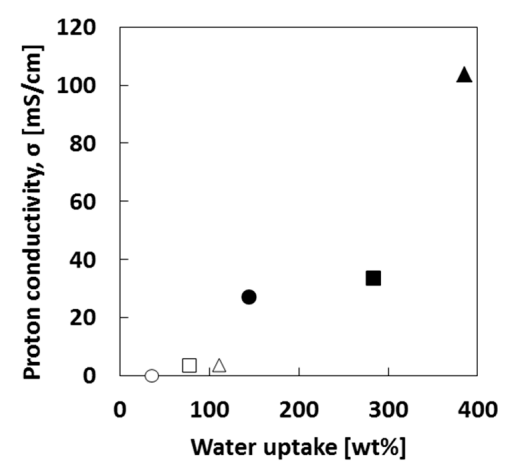

Figure 4. Proton conductivity of the PEMs as a function of water uptake. Chloromethyl group content in the polymers (mol \%): circles, 1.8; squares, 8.4; and triangles, 15.3. EtSS content in the reaction mixture (mmol): open symbols, 1.1 ; and solid symbols, 2.2 .

The PSF- $g$-PSSA PEMs prepared under conditions of $c^{\mathrm{P}}{ }_{\mathrm{CM}}=15.3 \mathrm{~mol} \%$ and EtSS $=2.2 \mathrm{mmol}$ (SF-6) exhibited $103 \mathrm{mS} \cdot \mathrm{cm}^{-1}$ of proton conductivity which is relatively lower than that of Nafion ${ }^{\circledR} 117$ $\left(136 \mathrm{mS} \cdot \mathrm{cm}^{-1}\right)$ at $60{ }^{\circ} \mathrm{C}$, though Nafion ${ }^{\circledR} 117$ has lower IEC $(0.91 \mathrm{meq} / \mathrm{g})$ than SF-6. In comparison with PEMs with almost the same IECs, SF-6 had higher proton conductivity than SF-4 because the former had higher water uptake than the latter.

Figure 5 shows methanol permeability as a function of water uptake. Methanol permeability also increases with increasing water uptake. SF-1 had much lower proton conductivity and methanol permeability than the other PEMs. This will be due to the fact that, in PEMs prepared from a graft copolymer, phase separation between the hydrophobic domains and the hydrophilic domains gives ionic aggregates (ionic clusters) of $-\mathrm{SO}_{3} \mathrm{H}$ inside the PEM [33]. A graft copolymer with longer Lav will give a lower density of the ionic clusters inside the PEM; hence, the number of ionic channels connected between the clusters will be lower than a PEM with shorter Lav, especially at low IEC. As SF-2 had higher IEC than SF-1, the larger size of the ionic domains led to a smaller distance between ionic clusters and a more extensive connection of ionic clusters. Hence, SF-2 had much higher values in the proton conductivity and methanol permeability than SF-1.

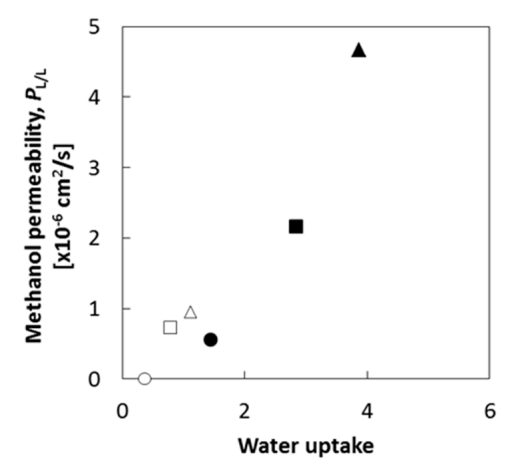

Figure 5. Methanol permeability of the PEMs as a function of water uptake. Chloromethyl group content in the polymers (mol \%): circles, 1.8; squares, 8.4; and triangles, 15.3. EtSS content in the reaction mixture (mmol): open symbols, 1.1; and solid symbols, 2.2 .

\subsection{Proton Permselectivity of the PEMs}

PEMs for DMFC applications should possess not only high proton conductivity but also a low permeability coefficient for methanol at the same time. Hence, as one of the important indices about 
PEM performance for DMFC, the proton permselectivity is defined as the division of the proton conductivity by the methanol permeability coefficient:

$$
\phi=\frac{\sigma}{p_{M, L / L}}
$$

The higher the proton permselectivity of a PEM, the more suitable it is for DMFC. Figure 6 shows proton permselectivity as a function of water uptake of the PEMs. The proton permselectivity increases with increasing water uptake due to the increase in the proton conductive paths in PEMs. SF-2 $\left(c^{\mathrm{P}} \mathrm{CM}=1.81\right.$ and $\left.I E C=0.83\right)$ achieved $48.6 \times 10^{3} \mathrm{~S} \cdot \mathrm{s} / \mathrm{cm}^{3}$ and had the highest proton permselectivity of all the PEMs.

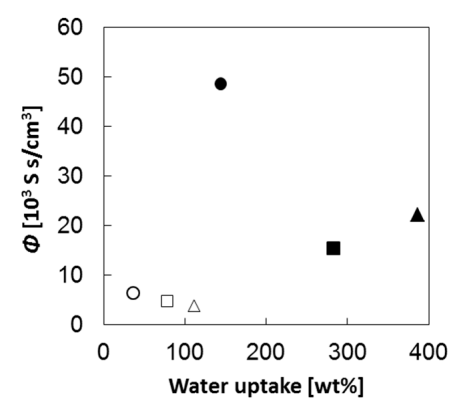

Figure 6. Proton permselectivity, $\phi$, of the PEMs as a function of water. Chloromethyl group content in the polymers (mol \%): circles, 1.8; squares, 8.4; and triangles, 15.3. EtSS content in the reaction mixture (mmol): open symbols, 1.1; and solid symbols, 2.2.

\subsection{Single Cell Performance of DMFC as a Function of $\mathrm{MeOH}$ Concentration}

From the six types of PEMs, SF-2, SF-5, and SF-6 were selected, and MEAs using the PEMs were prepared for the following single cell performance test of DMFC to investigate the relationship between the polymer structure and the DMFC performance of the PEMs. The three PEMs have different polymer structures to each other: SF-2 has a long average distance between the graft chains (Lav) and a long side chain length (Lsc); SF-5, short Lav and short Lsc; SF-6, short Lav and medium Lsc. Figure 7 shows an example of the single-cell performance test of a flow-type DMFC cell using an MEA with SF-6 at various methanol concentrations. From the experiments of the single-cell performance test, the open circuit voltage $(O C V)$ and maximum power density $\left(P D_{\max }\right)$ of the single-cell employing the three types of PEMs were obtained and are shown in Figures 8 and 9, respectively, as a function of methanol concentration in fuel. For comparison, the single-cell performance of Nafion ${ }^{\circledR} 112$ under similar conditions reported in literature [31] is also shown in these figures.

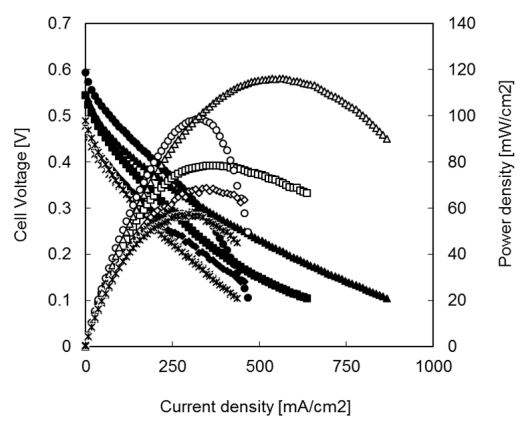

Figure 7. Cell voltage (solid symbols) and power density (open symbols) of the DMFC test cell with SF-6. Cell temperature, $60^{\circ} \mathrm{C}$. Anode: methanol solution $\left(1.0 \mathrm{~cm}^{3} / \mathrm{min}\right)$, Cathode: dry oxygen $\left(150 \mathrm{~N} \cdot \mathrm{cm}^{3} / \mathrm{min}\right.$ ) Methanol concentration in fuel (wt \%): circles, 3.2; and triangles, 10; squares, 20; diamonds, 30; and asterisks, 50. 


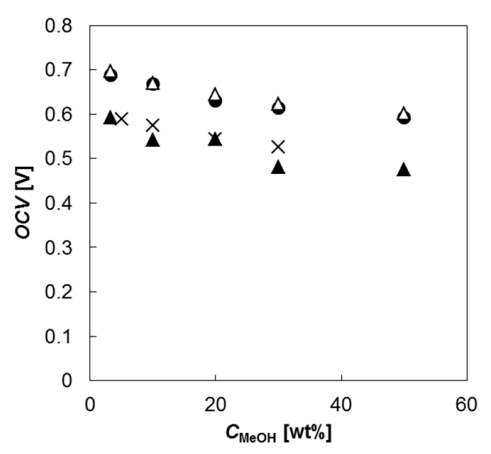

Figure 8. Open circuit voltage (OCV) of the cell with PSF- $g$-PSSA PEMs. Sample PEM: solid circles, SF-2; open triangles, SF-5; solid triangles, SF-6; and cross, Nafion 112 [31].

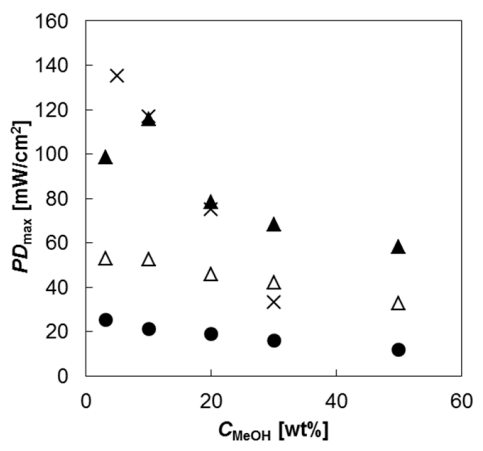

Figure 9. Maximum power density $\left(P D_{\max }\right)$ of the cell with PSF- $g$-PSSA PEMs. Sample PEM: solid circles, SF-2; open triangles, SF-5; solid triangles, SF-6; and cross, Nafion 112 [31].

The OCV of PSF-g-PSSA PEMs as well as Nafion ${ }^{\circledR} 112$ decreased gradually with increasing methanol concentration. Commonly, the $O C V$ value decreases with increasing methanol concentration in fuel, because of methanol crossover from anode to cathode through the PEM and the over-potential of the cathode as a result of poisoning of the cathode catalyst. SF- 2 and SF- 5 showed higher OCV than SF- 6 and Nafion ${ }^{\circledR} 112$ at all methanol concentrations.

The $P D_{\max }$ of all the PEMs, except SF-6, decreased with increasing methanol concentrations from $3.2 \mathrm{wt} \%$ to $20 \mathrm{wt} \%$. In contrast, the $P D_{\max }$ of SF-6 increased with increasing methanol concentration in fuel from $3.2 \mathrm{wt} \%$ to $10 \mathrm{wt} \%$. This will be due to the positive effect of an enhancement in the electrode reaction rate with an increase in fuel concentration which was more predominant than the negative effect of an increase in methanol crossover. However, by increasing from $10 \mathrm{wt} \%$ to $50 \mathrm{wt} \%$, DMFC performance decreased. This will be due to the negative effect being more predominant than the positive effect. SF-6 had the highest $P D_{\max }$ and SF-2 the lowest $P D_{\max }$ of all of the PSF- $g$-PSSA PEMs at all methanol concentrations.

In order to investigate the dependence of methanol concentration on the cell performance of DMFC, methanol permeability $\left(P_{\mathrm{DMFC}}\right)$, and proton conductivity $\left(\sigma_{\mathrm{DMFC}}\right)$ were measured in situ during DMFC operation using PSF- $g$-PSSA PEMs and are shown in Figures 10 and 11, respectively, as a function of methanol concentration. Proton selectivity $\left(\phi_{\mathrm{DMFC}}\right)$ during DMFC operation was calculated from $\sigma_{\mathrm{DMFC}}$ and $P_{\mathrm{DMFC}}$ and is shown in Figure 12 . Here, it is noted that $P_{\mathrm{DMFC}}$ refers to the value measured in situ during DMFC operation, whereas $P_{\mathrm{L} / \mathrm{L}}$ refers to the corresponding value measured ex situ by the liquid/liquid permeation method mentioned above. $P_{\mathrm{DMFC}}$ and $\phi_{\mathrm{DMFC}}$ of all the PSF- $g$-PSSA PEMs as well as Nation ${ }^{\circledR} 112$ hardly changed with methanol concentrations. In the order, Nafion ${ }^{\circledR} 112$, SF-6, SF-5 and SF-2, the PEMs had higher values of both $P_{\text {DMFC }}$ and $\sigma_{\text {DMFC }}$. $\phi_{\text {DMFC }}$ of SP-6 increased slightly while that of SF-2, SF-5 and Nafion ${ }^{\circledR} 112$ decreased with increasing methanol concentration. 


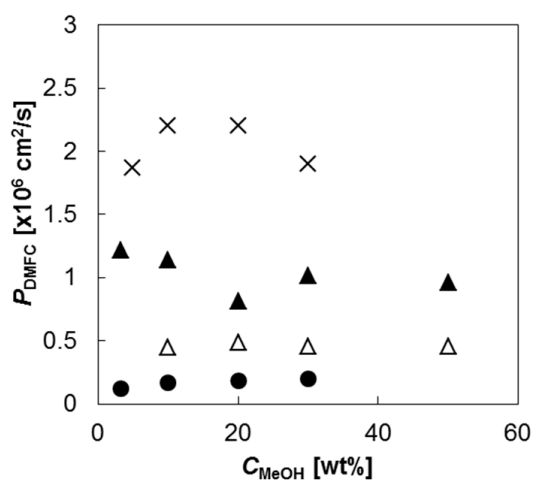

Figure 10. Methanol permeability $\left(P_{\mathrm{DMFC}}\right)$ during DMFC operation at $100 \mathrm{~mA} / \mathrm{cm}^{2}$ as a function of methanol concentration in fuel. Sample PEM: solid circles, SF-2; open triangles, SF-5; solid triangles, SF-6; and cross, Nafion112 [31]. Cell temperature, $60^{\circ} \mathrm{C}$.

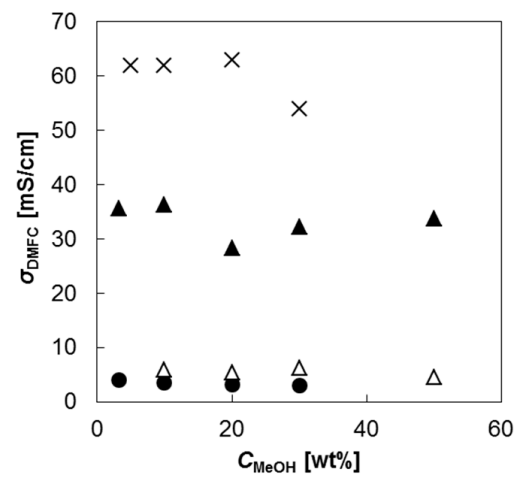

Figure 11. Proton conductivity $\left(\sigma_{\mathrm{DMFC}}\right)$ during DMFC operation at $100 \mathrm{~mA} / \mathrm{cm}^{2}$ as a function of methanol concentration in fuel. Sample PEM: solid circles, SF-2; open triangles, SF-5; solid triangles, SF-6; and cross, Nafion112 [31]. Cell temperature, $60{ }^{\circ} \mathrm{C}$.

OCV of Nafion ${ }^{\circledR} 112$ had almost the same values as that of SF- 6 though $P_{\text {DMFC }}$ of the former was about two times higher that of the latter. This will be due to the fact that the reactivity of the catalyst in the MEA with Nafion ${ }^{\circledR} 112$ was higher than that with SF-6, because the Nafion solution was used as a binder of the junction between the electrodes and the PEMs. Though SF-2 and SF-5 had higher OCV than SF-6 at all the methanol concentrations, $P D_{\max }$ of SF-2 and SF-5 was lower than that of SF- 6 because $\sigma_{\text {DMFC }}$ of the former was much lower than that of the latter, as shown in Figure 11. The $P D_{\max }$ of Nafion ${ }^{\circledR} 112$ had the highest values at low methanol concentrations; however, it decreased steeply with increasing methanol concentration. Hence, Nafion ${ }^{\circledR} 112$ had about half the value of $P D_{\max }\left(36 \mathrm{~mW} / \mathrm{cm}^{2}\right)$ compared with SF- $6\left(68.4 \mathrm{~mW} / \mathrm{cm}^{2}\right)$, at $30 \mathrm{wt} \%$ of methanol concentration. Furthermore, SF- 6 had $58.2 \mathrm{~mW} / \mathrm{cm}^{2}$ of $P D_{\max }$ at $50 \mathrm{wt} \%$ of methanol concentration while $P D_{\max }$ using Nafion ${ }^{\circledR}$ was too small a value to measure because it had the highest methanol crossover of all the PEMs.

As a conclusion about the relationship between the polymer structure and DMFC performance under our test conditions, a PSF-g-PSSA PEM prepared from a graft copolymer with short Lav and medium Lsc will have higher DMFC performance than one with long Lav and long Lsc, or one with short Lav and short Lsc, because the former has the highest proton selectivity during DMFC operation of all the PEMs. 


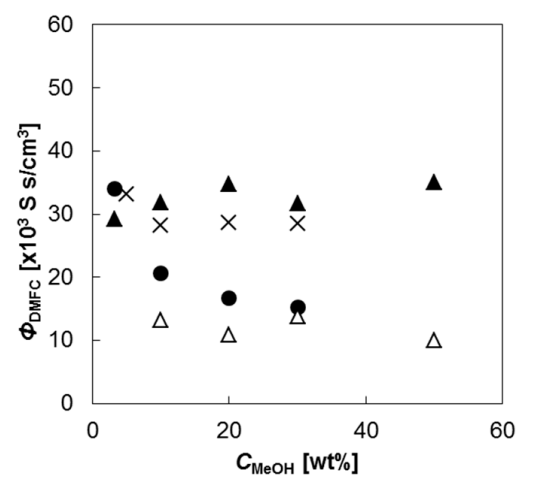

Figure 12. Proton permselectivity $\left(\phi_{\mathrm{DMFC}}\right.$ ) during DMFC operation at $100 \mathrm{~mA} / \mathrm{cm}^{2}$ as a function of methanol concentration in fuel. Sample PEM: solid circles, SF-2; open triangles, SF-5; solid triangles, SF-6; and cross, Nafion112 [31]. Cell temperature, $60{ }^{\circ} \mathrm{C}$.

In comparison of the methanol permeability between the in situ and ex situ experiments, $P_{\mathrm{L} / \mathrm{L}}$ showed a higher value than $P_{\mathrm{DMFC}}$. This will be to the fact that, during the ex situ experiments, a sample PEM contacted with deionized water; hence, the PEM will have a higher water uptake than that during the in situ experiments.

There have been many reports on the research and development of PEMs for DMFCs [34,35]. One of the challenges in DMFC research is to develop a PEM which can be used at high methanol concentrations $(>9.0 \mathrm{M}$ ) because the specific energy of a DMFC system can be higher than that of Li-ion batteries only if the methanol concentration in the fuel cartridge is higher than $9.0 \mathrm{M}$ [36]. Hence, the $O C V$ and the $P D_{\max }$ at high methanol concentrations (more than $9 \mathrm{M}$ ) and their measurement conditions reported in the literature are listed in Table 4 for comparison with our data. Hu et al. reported [31] that $P D_{\max }$ of a single cell with Nafion ${ }^{\circledR} 112$ using $9 \mathrm{M}(30 \mathrm{wt} \%)$ methanol feed was

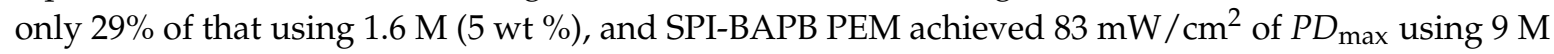
methanol which is $69 \%$ of that using $1.6 \mathrm{M}$ methanol. The PEM also achieved $70 \mathrm{~mW} / \mathrm{cm}^{2}$ of $P D_{\max }$ using $15.6 \mathrm{M}$ methanol. Chen et al. reported that SPI-DABI PEM showed $55 \mathrm{~mW} / \mathrm{cm}^{2}$ of $P D_{\max }$, which is lower than that for Nafion ${ }^{\circledR} 112$ [37]. Higa et al. reported that $P D_{\max }$ of Nafion ${ }^{\circledR} 117$ was almost zero using methanol concentrations above $10 \mathrm{M}$ [38]. In contrast, the $P D_{\max }$ of PVA-AMPS maintains an almost constant value with increasing methanol concentration. The $P D_{\max }$ with PVA- $b$-SSA PEMs was two times higher than that with Nafion ${ }^{\circledR} 115$ [39]. This indicates that the decrease in $P D_{\max }$ of PVA-based PEMs at high methanol concentrations is lower than that of other PEMs because of good methanol barrier properties of PVA-based PEMs. From the comparison, PSF-g-PSSA PEMs have the highest $P D_{\max }$ of all the PEMs, excepting SPI-BAPB PEM [31] whose methanol permeability is lower than PSF-g-PSSA PEMs. Hence, optimization of the PSF-g-PSSA polymer structure to reduce methanol permeability will give PSF- $g$-PSSA PEMs a higher DMFC performance. 
Table 4. Fuel cell performance and methanol permeability of representative PEMs in DMFC.

\begin{tabular}{|c|c|c|c|c|c|c|c|c|c|c|}
\hline PEM & $d^{1}(\mu \mathrm{m})$ & $\begin{array}{c}I E C \\
\text { (meq/g) }\end{array}$ & $\sigma^{2}(\mathrm{mS} / \mathrm{cm})$ & $\begin{array}{c}\text { Cell Temp. }\left({ }^{\circ} \mathrm{C}\right) \\
\text { Oxidant }\end{array}$ & $\mathrm{C}_{\mathrm{MeOH}}$ & $O C V(\mathrm{~V})$ & $\begin{array}{c}\mathrm{PD}_{\max } \\
\left(\mathrm{mW} / \mathrm{cm}^{2}\right)\end{array}$ & $\begin{array}{c}P_{\mathrm{DMFC}}^{3} \\
\left(10^{-6} \mathrm{~cm}^{2} / \mathrm{s}\right)\end{array}$ & $\begin{array}{c}\text { qDMFC }^{4} \\
\left(\mu \mathrm{mol} / \mathrm{cm}^{2} \cdot \mathrm{s}\right)\end{array}$ & Ref. \\
\hline \multirow{2}{*}{ SF-2 } & \multirow{2}{*}{60} & \multirow{2}{*}{0.83} & \multirow{2}{*}{27.1} & $\begin{array}{c}60 \\
\left(\mathrm{O}_{2}\right)\end{array}$ & $9 \mathrm{M}(30 \mathrm{wt} \%)$ & 0.62 & 16.1 & $\begin{array}{l}0.20 \\
(5.6)\end{array}$ & 0.68 & \\
\hline & & & & $\begin{array}{c}60 \\
\left(\mathrm{O}_{2}\right)\end{array}$ & $15.6 \mathrm{M}(50 \mathrm{wt} \%)$ & 0.59 & 11.9 & - & - & \\
\hline \multirow{2}{*}{ SF-5 } & \multirow{2}{*}{50} & \multirow{2}{*}{0.64} & \multirow{2}{*}{3.7} & $\begin{array}{c}60 \\
\left(\mathrm{O}_{2}\right)\end{array}$ & $9 \mathrm{M}(30 \mathrm{wt} \%)$ & 0.62 & 42.1 & $\begin{array}{l}0.46 \\
(9.5)\end{array}$ & 1.6 & \\
\hline & & & & $\begin{array}{c}60 \\
\left(\mathrm{O}_{2}\right) \\
\end{array}$ & $15.6 \mathrm{M}(50 \mathrm{wt} \%)$ & 0.60 & 32.8 & 0.46 & 2.6 & \\
\hline \multirow{2}{*}{ SF-6 } & \multirow{2}{*}{70} & \multirow{2}{*}{1.52} & \multirow{2}{*}{103.4} & $\begin{array}{c}60 \\
\left(\mathrm{O}_{2}\right)\end{array}$ & $9 \mathrm{M}(30 \mathrm{wt} \%)$ & 0.48 & 68.4 & $\begin{array}{c}1.0 \\
(4.7)\end{array}$ & 2.4 & \\
\hline & & & & $\begin{array}{c}60 \\
\left(\mathrm{O}_{2}\right) \\
\end{array}$ & $15.6 \mathrm{M}(50 \mathrm{wt} \%)$ & 0.48 & 58.2 & 1.0 & 3.9 & \\
\hline \multirow{2}{*}{$\begin{array}{c}\text { NHDTA-BAPBDS/ } \\
\text { BAPB }(1 / 1)\end{array}$} & \multirow{2}{*}{53} & \multirow{2}{*}{1.51} & \multirow{2}{*}{64} & $\begin{array}{c}60 \\
\left(\mathrm{O}_{2}\right)\end{array}$ & $9 \mathrm{M}(30 \mathrm{wt} \%)$ & 0.61 & 83 & 0.52 & 0.92 & \multirow{2}{*}{ [31] } \\
\hline & & & & $\begin{array}{c}60 \\
\left(\mathrm{O}_{2}\right) \\
\end{array}$ & $15.6 \mathrm{M}(50 \mathrm{wt} \%)$ & 0.61 & 70 & 0.52 & 1.53 & \\
\hline Nafion112 & 55 & 0.91 & 136 & $\begin{array}{c}60 \\
\left(\mathrm{O}_{2}\right) \\
\end{array}$ & $9 \mathrm{M}(30 \mathrm{wt} \%)$ & 0.53 & 36 & 1.9 & 3.2 & [31] \\
\hline $\begin{array}{c}\text { NHDTA-BAPBDS/ } \\
\text { p-DABI }(2 / 1)\end{array}$ & 54 & 1.77 & 75 & $\begin{array}{c}60 \\
\left(\mathrm{O}_{2}\right) \\
\end{array}$ & $9 \mathrm{M}(30 \mathrm{wt} \%)$ & 0.60 & 55 & 0.48 & 0.82 & [37] \\
\hline PVA-AMPS & & 0.30 & $12.9\left(25^{\circ} \mathrm{C}\right)$ & $\begin{array}{c}25 \\
\text { (air) }\end{array}$ & $20 \mathrm{M}$ & 0.36 & 1.6 & $(0.1)$ & - & [38] \\
\hline Nafion117 & & 0.91 & $90\left(25^{\circ} \mathrm{C}\right)$ & $\begin{array}{c}25 \\
\text { (air) }\end{array}$ & $20 \mathrm{M}$ & 0.05 & 0 & (3.0) & - & [38] \\
\hline PVA- $b$-SSA & 62 & 0.95 & 14.0 & $\begin{array}{c}60 \\
\left(\mathrm{O}_{2}\right) \\
\end{array}$ & $9 \mathrm{M}$ & 0.54 & 17.8 & $(0.89)$ & - & [39] \\
\hline Nafion115 & 140 & 0.91 & 90 & $\begin{array}{c}60 \\
\left(\mathrm{O}_{2}\right)\end{array}$ & $9 \mathrm{M}$ & 0.41 & 9.6 & (3.0) & - & [39] \\
\hline
\end{tabular}

${ }^{1}$ Membrane thickness; ${ }^{2}$ Proton conductivity at $60{ }^{\circ} \mathrm{C} ;{ }^{3}$ Methanol permeability of membrane during DMFC operation; the data in parentheses are obtained by the liquid /liquid permeation method $\left(P_{\mathrm{L} / \mathrm{L}}\right) ;{ }^{4}$ Methanol flux of membrane during DMFC operation. 


\section{Conclusions}

In this study, PEMs for DMFCs were prepared from graft copolymers (PSF- $g$-PSSA) consisting of a polysulfone (PSF) main chain and poly(styrene sulfonic acid) (PSSA) side chains with various average distances between side chains (Lav) and side chain lengths (Lsc). The correlation between the polymer structures and the properties of the PEMs for DMFC was investigated.

The DMFC performance tests using MEAs with the three types of the PEMs prepared from the graft copolymers with different polymer structures revealed that: a PSF-g-PSSA PEM prepared from a graft copolymer with short average distances between side chains (Lav) and medium Lsc (SF-6) had higher DMFC performance than that with long Lav and long Lsc or with short Lav and short Lsc because the former has the highest proton selectivity of all the PEMs.

SF-6 had $P D_{\max }\left(68.4 \mathrm{~mW} / \mathrm{cm}^{2}\right)$ about two times higher than Nafion ${ }^{\circledR} 112\left(36 \mathrm{~mW} / \mathrm{cm}^{2}\right)$ at $30 \mathrm{wt} \%$ of methanol concentration. Furthermore, SF-6 had $58.2 \mathrm{~mW} / \mathrm{cm}^{2}$ of $P D_{\max }$ at $50 \mathrm{wt} \%$ of methanol concentration because of it had the highest proton selectivity during DMFC operation of all the PSF-g-PSSA PEMs and Nafion ${ }^{\circledR} 112$. Therefore, PSF- $g$-PSSA graft copolymers with short average distances between side chains (Lav) and medium Lsc will be suitable for DMFC applications at high methanol concentrations. This perception should provide valuable insights into the design of PEMs for fuel cell applications.

Acknowledgments: This work was partly supported by a Grant-in-Aid for Scientific Research (C) (No. 26420724) from the Japan Society for the Promotion of Science and by the Salt Science Research Foundation Grant No. 1504.

Author Contributions: Mitsuru Higa and Nobutaka Endo conceived and designed the experiments; Nobutaka Endo, Yoshiaki Ogawa and Kohei Ukai performed the experiments; Mitsuru Higa and Nobutaka Endo analyzed the data; Yuriko Kakihana contributed reagents/materials/analysis tools; Mitsuru Higa and Nobutaka Endo wrote the paper.

Conflicts of Interest: The authors declare no conflict of interest.

\section{References}

1. Hampson, N.A.; Wilars, M.J.; McNicol, B.D. The methanol-air fuel cell: A selective review of methanol oxidation mechanisms at platinum electrodes in acid electrolytes. J. Power Sources 1979, 4, 191-201. [CrossRef]

2. Ren, X.; Wilson, M.S.; Gottefeld, S. High performance direct methanol polymer electrolyte fuel cells. J. Electrochem. Soc. 1996, 143, L12-L15. [CrossRef]

3. Rikukawa, M.; Sanui, K. Proton-conducting polymer electrolyte membranes based on hydrocarbon polymers. Prog. Polym. Sci. 2000, 25, 1463-1502. [CrossRef]

4. Smitha, B.; Sridhar, S.; Khan, A.A. Solid polymer electrolyte membranes for fuel cell applications-A review. J. Membr. Sci. 2005, 259, 10-26. [CrossRef]

5. Bogolowski, N.; Drillet, J.-F. Appropriate balance between methanol yield and power density in portable direct methanol fuel cell. Chem. Eng. J. 2015, 270, 91-100. [CrossRef]

6. Lin, J.; Wu, P.-H.; Wycisk, R.; Pintauro, P.N.; Shi, Z. Properties of water in prestretched recast Nafion. Macromolecules 2008, 41, 4284-4289. [CrossRef]

7. Lin, J.; Wu, P.-H.; Wycisk, R.; Trivisonno, A.; Pintauro, P.N. Direct methanol fuel cell operation with pre-stretched recast Nafion. J. Power Sources 2008, 183, 491-497. [CrossRef]

8. Park, Y.-C.; Peck, D.-H.; Kim, S.-K.; Lim, S.; Jung, D.-H.; Lee, D.-Y. Operation of a direct methanol fuel cell stack by self-heating at low temperatures. Int. J. Hydrog. Energy 2011, 36, 5655-5665. [CrossRef]

9. Yang, W.W.; Zhao, T.S.; Wu, Q.X. Modeling of a passive DMFC operating with neat methanol. Int. J. Hydrog. Energy 2011, 36, 6899-6913. [CrossRef]

10. Elabd, Y.A.; Napadensky, E.; Sloan, J.M. Triblock copolymer ionomer membranes Part I. Methanol and proton transport. J. Membr. Sci. 2003, 217, 227-242. [CrossRef]

11. Kim, Y.S.; Sumner, M.J.; Harrison, W.L.; Riffle, J.S.; McGrath, J.E.; Pivovar, B.S. Direct Methanol Fuel Cell Performance of Disulfonated Polyarylene ether benzonitrile Copolymers. Electrochem. Soc. 2004, 151, A2150-A2156. [CrossRef]

12. Fu, Y.Z.; Manthiram, A. Synthesis and characterization of sulfonated polysulfone membranes for direct methanol fuel cells. J. Power Sources 2006, 157, 222-225. [CrossRef] 
13. Hill, M.L.; Kim, Y.S.; Einsla, B.R.; McGrath, J.E. Zirconium hydrogen phosphate/disulfonated poly(arylene ether sulfone) copolymer composite membranes for proton exchange membrane fuel cells. J. Membr. Sci. 2006, 283, 102-108. [CrossRef]

14. Lufrano, F.; Baglio, V.; Staiti, P.; Arico, A.S.; Antonucci, V. Polymer electrolytes based on sulfonated polysulfone for direct methanol fuel cells. J. Power Sources 2008, 179, 34-41. [CrossRef]

15. Kim, Y.S.; Kim, D.S.; Liu, B.; Guiver, M.D.; Pivovar, B.S. Copoly(arylene ether nitrile)s-High-Performance Polymer Electrolytes for Direct Methanol Fuel Cells. J. Electrochem. Soc. 2008, 155, B21-B26. [CrossRef]

16. Li, L.; Zhang, J.; Wang, Y.X. Sulfonated poly(ether ether ketone) membranes for direct methanol fuel cell. J. Membr. Sci. 2013, 226, 159-167. [CrossRef]

17. Silva, V.S.; Ruffmann, B.; Vetter, S.; Boaventura, M.; Mendes, A.M.; Madeira, L.M.; Nunes, S.P. Mass transport of direct methanol fuel cell species in sulfonated poly(ether ether ketone) membranes. Electrochim. Acta 2006, 51, 3699-3706. [CrossRef]

18. Yin, Y.; Fang, J.H.; Cui, Y.F.; Tanaka, K.; Kita, H.; Okamoto, K. Synthesis, proton conductivity and methanol permeability of a novel sulfonated polyimide from 3-(20,40-diaminophenoxy) propane sulfonic acid. Polymer 2003, 44, 4509-4518. [CrossRef]

19. Miyatake, K.; Zhou, H.; Matsuo, T.; Uchida, H.; Watanabe, M. Proton Conductive Polyimide Electrolytes Containing Trifluoromethyl Groups: Synthesis, Properties, and DMFC Performance. Macromolecules 2004, 37, 4961-4966. [CrossRef]

20. Einsla, B.R.; Kim, Y.S.; Hickner, M.A.; Hong, Y.T.; Hill, M.L.; Pivovar, B.S.; McGrath, J.E. Sulfonated naphthalene dianhydride based polyimide copolymers for proton-exchange-membrane fuel cells II. Membrane properties and fuel cell performance. J. Membr. Sci. 2005, 255, 141-148. [CrossRef]

21. Okamoto, K.; Yin, Y.; Yamada, O.; Islam, M.N.; Honda, T.; Mishima, T.; Suto, Y.; Tanaka, K.; Kita, H. Methanol permeability and proton conductivity of sulfonated co-polyimide membranes. J. Membr. Sci. 2005, 258, 115-122. [CrossRef]

22. Yin, Y.; Yamada, O.; Tanaka, K.; Okamoto, K. On the Development of Naphthalene-Based Sulfonated Polyimide Membranes for Fuel Cell Applications. Polym. J. 2006, 38, 197-219. [CrossRef]

23. Song, J.M.; Miyatake, K.; Uchida, H.; Watanabe, M. Investigation of direct methanol fuel cell performance of sulfonated polyimide membrane. Electrochim. Acta 2006, 51, 4497-4504. [CrossRef]

24. Zhai, F.X.; Guo, X.X.; Fang, J.H.; Xu, H.J. Synthesis and properties of novel sulfonated polyimide membranes for direct methanol fuel cell application. J. Membr. Sci. 2007, 296, 102-109. [CrossRef]

25. Zhang, M.F.; Russell, T.P. Graft Copolymers from Poly(vinylidene fluoride-co-chlorotrifluoroethylene) via Atom Transfer Radical Polymerization. Macromolecules 2006, 39, 3531-3539. [CrossRef]

26. Tsang, E.M.W.; Zhang, Z.; Shi, Z.; Soboleva, T.; Holdcroft, S. Considerations of Macromolecular Structure in the Design of Proton Conducting Polymer Membranes: Graft versus Diblock Polyelectrolytes. J. Am. Chem. Soc. 2007, 129, 15106-15107. [CrossRef] [PubMed]

27. Higa, M.; Yaguchi, K.; Kitani, R. All solid-state polymer electrolytes prepared from a graft copolymer consisting of a polyimide main chain and poly(ethylene oxide) based side chains. Electrochim. Acta 2010, 55, 1380-1384. [CrossRef]

28. Xu, F.J.; Zhao, J.P.; Kang, E.T.; Neoh, K.G. Surface functionalization of polyimide films via chloromethylation and surface-initiated atom transfer radical polymerization. Ind. Eng. Chem. Res. 2007, 46, 4866-4873. [CrossRef]

29. Kakihana, Y.; Ogawa, Y.; Takamura, K.; Hara, R.; Higa, M. Characterization of cation-exchange membranes prepared from agraft-copolymer consisting of a polysulfone main chain and styrenesulfonic acid side chains. Electrochim. Acta 2014, 129, 120-126. [CrossRef]

30. Higa, M.; Sugita, M.; Maesowa, S.-I.; Endo, N. Poly(vinyl alcohol)-based polymer electrolyte membranes for direct methanol fuel cells. Electrochim. Acta 2010, 55, 1445-1449. [CrossRef]

31. Hu, Z.; Ogou, T.; Yoshino, M.; Yamada, O.; Kita, H.; Okamoto, K. Direct methanol fuel cell performance of sulfonated polyimide membranes. J. Power Sources 2009, 194, 674-682. [CrossRef]

32. Qiao, J.; Hamaya, T.; Okada, T. New highly proton-conducting membrane poly(vinyl- pyrrolidone)(PVP) modified poly(vinyl alcohol)/2-acrylamido-2-methyl-1-propanesulfonic acid (PVA-PAMPS) for low temperature direct methanol fuel cells (DMFCs). Polymer 2005, 46, 10809-10816. [CrossRef] 
33. Tsang, E.M.W.; Zhang, Z.; Yang, A.C.C.; Shi, Z.; Peckham, T.J.; Narimani, R.; Frisken, B.J.; Holdcroft, S. Nanostructure, Morphology, and Properties of Fluorous Copolymers Bearing Ionic Grafts. Macromolecules 2009, 42, 9467-9480. [CrossRef]

34. Ahmad, H.; Kamarudin, S.K.; Hasran, U.A.; Saud, W.R.W. Overview of hybrid membranes for direct-methanol fuel-cell applications. Int. J. Hydrog. Energy 2010, 35, 2160-2175. [CrossRef]

35. Lufrano, F.; Baglio, V.; Staiti, P.; Antonucci, V.; Arico', A.S. Performance analysis of polymer electrolyte membranes for direct methanol fuel cells. J. Power Sources 2013, 243, 519-534. [CrossRef]

36. Zhao, T.S.; Yang, W.W.; Chen, R.; Wu, Q.X. Towards operating direct methanol fuel cells with highly concentrated fuel. J. Power Sources 2010, 195, 3451-3462. [CrossRef]

37. Chen, K.; Hu, Z.; Endo, N.; Fang, J.; Higa, M.; Okamoto, K. Sulfonated polyimides bearing benzimidazole groups for direct methanol fuel cell applications. J. Membr. Sci. 2010, 351, 214-221. [CrossRef]

38. Higa, M.; Hatemura, K.; Sugita, M.; Maesowa, S.; Nishimura, M.; Endo, N. Performance of passive direct methanol fuel cell with poly(vinyl alcohol)-based polymer electrolyte membranes. Int. J. Hydrog. Energy 2012, 37, 6292-6301. [CrossRef]

39. Higa, M.; Feng, S.; Endo, N.; Kakihana, Y. Characteristics and direct methanol fuel cell performance of polymer electrolyte membranes prepared from poly(vinyl alcohol-b-styrene sulfonic acid). Electrochim. Acta 2015, 153, 83-89. [CrossRef]

(C) 2016 by the authors; licensee MDPI, Basel, Switzerland. This article is an open access article distributed under the terms and conditions of the Creative Commons Attribution (CC-BY) license (http:/ / creativecommons.org/licenses/by/4.0/). 